\title{
Usage of Production Function in Linear Economy
}

\author{
Mária Szalmáné Csete, Diana Esses* \\ ${ }^{1}$ Department of Environmental Economics and Sustainability, Faculty of Economic and Social Sciences, Budapest University of \\ Technology and Economics, H-1111 Budapest, Muegyetem rkp. 3., Hungary \\ * Corresponding author, e-mail: esses.diana@gtk.bme.hu
}

Received: 06 June 2020, Accepted: 07 June 2020, Published online: 11 February 2022

\begin{abstract}
In this study, the Cobb Douglas production function was built in order to investigate the linear economy, the redesign of intralogistics in a company. Authors have investigated a production function that describes the connection between the production of liquids, energy efficiency and water usage based on the logistic processes. The authors were able to build and simplify it to a linearized Cobb Douglas equation. With the help of mathematical-statistical analysis, the authors found that energy efficiency and water usage have a negative effect on production due to European legal considerations and logistic improvement could help in the solution of the problem. Then, the differences between the linear economy and the circular economy were examined. As a summary, a SWOT analysis exploring the differences was prepared.
\end{abstract}

Keywords

circular economy, linear model, production theory, production function

\section{Introduction}

Nowadays, there is a growing acceptance of the idea that the transition to sustainability is critical (Szalmáné Csete and Buzási, 2020). Under severe social pressure, more and more companies are developing and applying new, innovative business models for more sustainable production (Torok et. al., 2018). Industrial production has been characterized as a linear model since the Industrial Revolution (Torok et al., 2014). Between 1970 and 2017, global material extraction tripled and continues to grow. Global material extraction is a global risk (Mulvaney, 2019). The production of companies consists of the following elements in the linear model: resources are extracted, combined and processed, consumed and then discarded. Policy efforts to promote sustainability have focused primarily on the final stage of the linear process, through waste management, recycling, and reuse (Hartley et al., 2020). Most of the natural resources used as raw materials are scarce, and these are mostly irreplaceable or only very expensive to replace (Csete et al., 2013; Harazin and Pálvölgyi, 2014). Economic activities are based on use of natural resources (Zilahy, 2016). Therefore, resource scarcity also affects the economic segment, where emerging competition extends commodity prices and leads to various price fluctuations (Hartley et al., 2020). The circular economy offers an opportunity to expand sustainable and labor-intensive economic activities. In March 2020, the EU adopted an action plan for a new circular economy in its industrial strategy (Mulvaney, 2019). According to the UNIDO plan (Finnish Innovation Fund, 2017), there are four steps to use and improve raw materials in Fig. 1.

State-of-the-art knowledge of the circular economy has recently achieved significant growth in several areas (Stahel, 2016). There are many approaches in the literature about the circular economy from sustainability, environmental, and economic perspectives (Murray et al., 2017; Koltai and Uzonyi-Kecskés, 2017).

Kirchherr et al. (2018) summarized the objectives of the model, which are based on 114 definitions in the literature, according to which one of the basic ideas of the circular

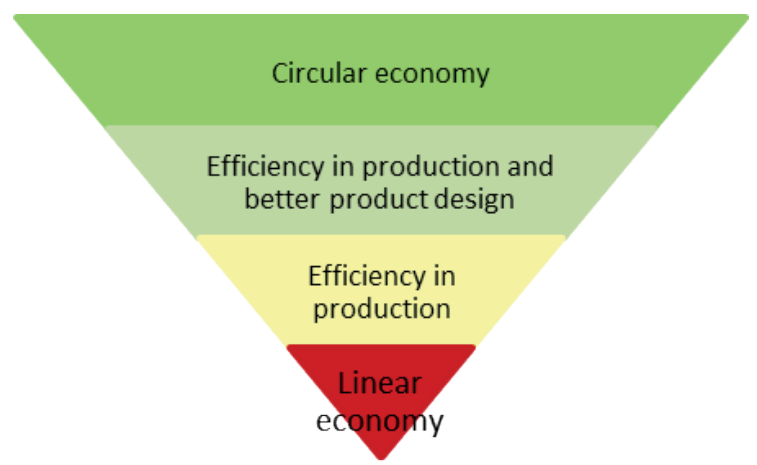

Fig. 1 UNIDO plan's 4 'stepping stones' (source: own edition based on UNIDO, 2017) 
economy is to achieve the goals of environmental sustainability, economic well-being, and social equity.

According to Kirchherr, "the circular economy is an economic system that replaces the concept of the 'life cycle' by alternatively reducing, reusing, recycling and reusing materials in production/distribution and consumption processes" (Hartley et al., 2020). The transition from a linear economy to a circular economy requires new consumption patterns and sustainable production. To this end, the Ellen MacArthur Foundation (2015) created a framework for multi-business models based on the goals of the circular economy, called ReSOLVE. The main models of the framework are: Regenerate, Share, Optimise, Loop, Virtualise, Exchange. (Chiappetta Jabbour et al., 2019) Water and water management is pivotal not only for the natural environment and essential for life, but also for socio-economic processes. Based on the White Paper of the Arup et al. (2018), the interconnections between the three circular economy principles (design out externalities, keep resources in use, regenerate capital) and water systems management were also identified, establishing a common understanding of the water-specific circular economic systems both in the case of human and nature managed systems. There are various motivating factors for, but also obstacles to the transition to a circular economy. According to Ritzén and Sandström (2017), there are five main obstacles to the introduction of a circular economy:

- Financial: The low price of the raw material does not allow for an increase in income with the introduction of the circular economy.

- Structural: communication difficulties between departments and throughout the supply chain

- Functional: lack of operational capacity and infrastructure to operate a circular economy.

- Attitude: they do not recognize the importance of the circular economy, they are afraid of changes, their behavior is characterized by risk aversion

- Technological: there are difficulties in integrating the circular economy into product design and manufacturing processes. (Chiappetta Jabbour et al., 2020)

In economics, production function is an equation that expresses the relationship between the quantities of productive factors and the amount of product obtained. It states the amount of product that can be obtained from every combination of factors, assuming that the most efficient available methods of production are used.
In this paper, the hypothesis is that the production of a single firm could be described with the usage production function, whereas logistics can highly influence production parameters.

The second chapter describes the methodology and the applied mathematical-statistical tools. The third chapter gives information on preliminary results, the fourth chapter analyses the results and gives a detailed statistical analysis. In the end, the conclusion was given.

\section{Methodology}

Data were collected from an online statistical source. Based on the available online data, the production factors were considered as an artificially created effectiveness index based on used energy and water usage and intralogistics processes. The results were generated in a manner consistent with accepted practice, as the basis of the statistical analysis. Hypothesis test and ANOVA analysis were used to prove the hypothesis (Fig. 2):

The well-known Cobb Douglas production function was used Eq. (1):

$Y=c \cdot X_{1}^{a_{1}} \cdot X_{2}^{a_{2}}$.

In order to have a further statistical analysis of regression the linearization is as follows Eq. (2):

$\ln (Y)=\ln (c)+a_{1} \cdot X_{1}+a_{2} \cdot X_{2}$.

One can see the well-known multilinear model in Eq. (2).

\section{Results}

The adjusted $\mathrm{R}$ square is 0.91 , which is internationally acceptable, and the $\mathrm{F}$ test showed that our production model is significant $(0.04)$ see Table 1.

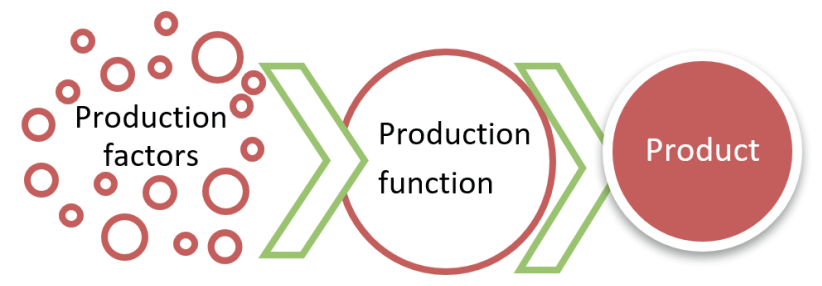

Fig. 2 Schema of the production function (source: own edition)

Table 1 Statistics of regression

\begin{tabular}{ll}
\hline $\mathrm{r}$ & 0.977909365 \\
$\mathrm{r}^{2}$ & 0.956306726 \\
adjusted $\mathrm{r}^{2}$ & 0.912613453 \\
Standard error & 0.055068764 \\
\hline
\end{tabular}

source: own edition 
Cobb-Douglas production function was used to describe the simple production unit in a linear economy. Regression analysis was done in order to estimate the linearized CobbDouglas equation (Table 2).

Both production factors have negative parameters of the slope in the linearized model.

\section{Discussion}

Negative elasticity of production function could be described due to the phenomena of decreasing effectiveness of production or logistics and water usage. These parameters are under the influence of the increasing stringency of European regulation Eq. (3):

$$
\ln (Y)=7.808-0.002 \cdot X_{1}-1.13 \cdot 10^{-7} \cdot X_{2}
$$

Comparative analysis of measured and calculated data shows that with the error of approximately $7 \%$, the calculated data are in in-line with measured data (Fig. 3 and Table 3):

Table 2 Coefficients of regression

\begin{tabular}{lc}
\hline & Coefficients \\
\hline Intercept & 7.80847 \\
$\mathrm{X}_{1}$ & -0.00268 \\
$\mathrm{X}_{2}$ & $-1.138 * 10-7$ \\
\hline
\end{tabular}

source: own edition

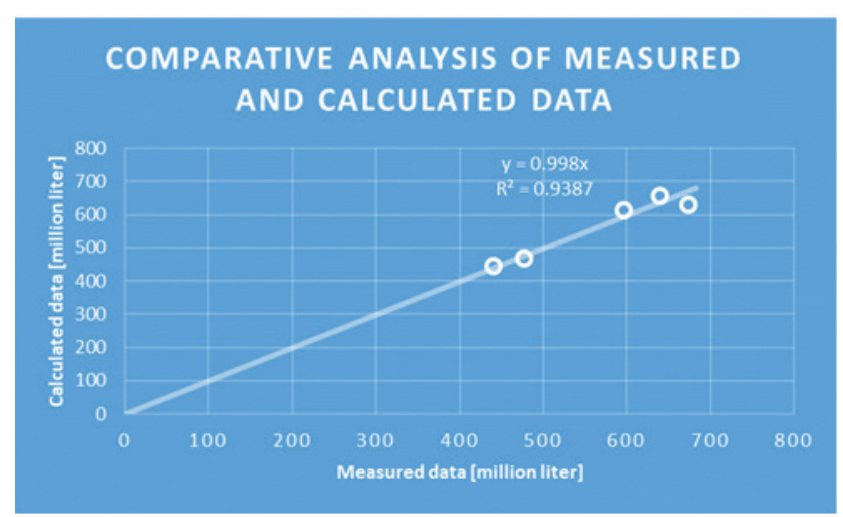

Fig. 3 Comparative analysis of measured and calculated data (source: own edition)

Table 3 Statistics of errors

\begin{tabular}{lc}
\hline Year & Relative error \\
\hline 2018 & $-5.85 \%$ \\
2017 & $3.20 \%$ \\
2016 & $3.04 \%$ \\
2015 & $-1.68 \%$ \\
2014 & $1.59 \%$ \\
\hline
\end{tabular}

source: own edition
As mentioned in the introduction, the circular economy has many economic benefits, but it also has its difficulties. Based on Sariatli's (2017) article, we conducted a summary SWOT analysis of the differences between the linear and circular economy (Table 4).

The circular economy makes it easier to manage waste and recycle resources. For organizations, in addition to sustainability, it also means competitive advantage and economic gain.

In the circular economy compared to the linear model, there is a quantifiable benefit of removing waste from the value chain and direct material cost reduction, as well as reducing the organization's resource dependence. Due to closedloop processes, the economy will be less exposed to material price fluctuations and more efficient use of resources.

There is no internationally recognized standard for sectors to implement a circular economy. The circular economy has opportunities and threats too. Due to the circular economy, the whole life cycle is examined, and close collaborations are formed, which can create an opportunity to form cartels (Sariatli, 2017).

\section{Conclusion}

In this paper, we examined a linear economy using the Cobb Douglas production function and then we discussed the differences between the linear model and the circular economy with a SWOT analysis. We used a production function that describes the relationship between fluid production, energy efficiency, and water use based on logistics processes. The hypothesis is proven that the production of a single firm can be described with the usage production function.

Research shows that the introduction of a circular economy has many sustainability, economic and social benefits. Besides, the transition from a linear model to a circular economy has difficulties, but this study proves too that it is worth overcoming obstacles.

Table 4 SWOT analysis of the differences between the linear and circular economy

\begin{tabular}{ll}
\hline Strengths & Weaknesses \\
- less waste & missing standard for other \\
- economic benefits & sectors \\
- less material dependence & it is not considered effective \\
- resource efficiency & by the public \\
\hline $\begin{array}{l}\text { Opportunities } \\
\text { - safer }\end{array}$ & \\
- right & Threats \\
- cheaper & increased risk of cartel \\
- new business opportunities & formation \\
\hline
\end{tabular}

Sources: own edition based on Sariatli, 2017 


\section{Acknowledgement}

This paper was supported by the János Bolyai Research Scholarship of the Hungarian Academy of Sciences. The research reported in this paper and carried out at BME has

\section{References}

Arup, Antea Group, Ellen MacArthur Foundation (2018) "Water and Circular Economy: A White Paper", [pdf] Arup, Antea Group, Ellen MacArthur Foundation, Available at: https://www.ellenmacarthurfoundation.org/assets/downloads/ce100/Water-andCircular-Economy-White-paper-WIP-2018-04-13.pdf [Accessed: 21 December 2018]

Chiappetta Jabbour, C. J. , Sarkis, J., Lopes de Sousa Jabbour, A. B., Renwick, D. W. S., Singh, S. K., Grebinevych, O., Kruglianskas, I., Filho, M. G. (2019) "Who is in charge? A review and a research agenda on the 'human side' of the circular economy", Journal of Cleaner Production, 222, pp. 793-801. https://doi.org/10.1016/j.jclepro.2019.03.038

Chiappetta Jabbour, C. J., Seuring, S., Lopes de Sousa Jabbour, A. B., Jugend, D., De Camargo Fiorini, P., Latan, H., Izeppi, W. C. (2020) "Stakeholders, innovative business models for the circular economy and sustainable performance of firms in an emerging economy facing institutional voids", Journal of Environmental Management, 264, Article No: 110416. https://doi.org/10.1016/j.jenvman.2020.110416

Ellen MacArthur Foundation (2015) "Schools of thought - performance economy", [online] Available at: https://www.ellenmacarthurfoundation.org/circular-economy/schools-of-thought/performanceeconomy [Accessed: 21 December 2016]

Finnish Innovation Fund (SITRA) (2017) "UNIDO at the World Circular Economy Forum (WCEF 2017)", Finnish Innovation Fund (SITRA), Helsinki, Finland.

Harazin, P., Pálvölgyi, T. (2014) "Erőforrás-hatékonysági tervezési platform koncepcionális és megvalósíthatósági tanulmány bemutatása", Energiagazdálkodás 55(1), pp. 37-40. Available at: https://issuu.com/ete01/docs/enga-2014-1-szam/42 [Accessed: 04 February 2020]

Hartley, K., van Santen, R., Kirchherr, J. (2020) "Policies for transitioning towards a circular economy: Expectations from the European Union (EU)", Resources, Conservation and Recycling, 155, Article No: 104634

https://doi.org/10.1016/j.resconrec.2019.104634

Kirchherr, J., Piscicelli, L., Bour, R., Kostense-Smit, E., Muller, J., Huibrechtse-Truijens, A., Hekkert, M. (2018) "Barriers to the Circular Economy: Evidence From the European Union (EU)", Ecological Economics, 150, pp. 264-272. https://doi.org/10.1016/j.ecolecon.2018.04.028

Koltai, T., Uzonyi-Kecskés, J. (2017) "The Comparison of Data Envelopment Analysis (DEA) and Financial Analysis Results in a Production Simulation Game", Acta Polytechnica Hungarica, 14(4), pp. 167-185.

https://doi.org/10.12700/APH.14.4.2017.4.10 been supported by the NRDI Fund (TKP2020 IES, Grant No. BME-IE-WAT) based on the charter of bolster issued by the NRDI Office under the auspices of the Ministry for Innovation and Technology.

Mulvaney, D. (2019) "Green New Deal", In: Solar Power: Innovation, Sustainability, and Environmental Justice, University of California Press, pp. 47-65. https://doi.org/10.2307/j.ctvd1c6zh.7

Murray, A., Skene, K., Haynes, K. (2017) "The Circular Economy: An Interdisciplinary Exploration of the Concept and Application in a Global Context", Journal of Business Ethics, 140, pp. 369-380. https://doi.org/10.1007/s10551-015-2693-2

Ritzén, S., Sandström, G. Ö. (2017) "Barriers to the Circular Economy - Integration of Perspectives and Domains", Procedia CIRP, 64, pp. 7-12. https://doi.org/10.1016/j.procir.2017.03.005

Sariatli, F. (2017) "Linear Economy Versus Circular Economy: A Comparative and Analyzer Study for Optimisation of Economy for Sustainability", Visegrad Journal on Bioeconomy and Sustainable Development, 6(1), pp. 31-34. https://doi.org/10.1515/vjbsd-2017-0005

Stahel, W. R. (2016) "The circular economy", Nature, 531, pp. 435-438. https://doi.org/10.1038/531435a

Szalmáné Csete, M., Buzási, A. (2020) " A smart planning szerepe a fenntartható városfejlesztésben " (The role of smart planning in sustainable urban development), Területi Statisztika, 60(3), pp. 370-390. (in Hungarian) https://doi.org/10.15196/TS600304

Torok, A., Derenda, T., Zanne, M., Zoldy, M. (2018) "Automatization in road transport: a review", Production Engineering Archives, 20(20), pp. 3-7. https://doi.org/10.30657/pea.2018.20.01

Torok, A., Torok, A., Heinitz, F. (2014) "Usage of Production Functions in the Comparative Analysis of Transport Related Fuel Consumption", Transport and Telecommunication Journal, 15(4), pp. 292-298. https://doi.org/10.2478/ttj-2014-0025

Zilahy, G. (2016) "Sustainable Business Models - What Do Management Theories Say?", Vezetéstudomány - Budapest Management Review, 47(10), pp. 62-72. https://doi.org/10.14267/VEZTUD.2016.10.06 